\title{
Lercaro y el principio de la arquitectura moderna al servicio de la liturgia
}

\author{
Lercaro and the principle of modern architecture at the service of the liturgy
}

Glauco Gresleri

https://doi.org/10.17979/aarc.2009.2.1.5037

\section{PRESENTACIÓN}

Lo que voy a relatar en este foro tan acreditado, es la historia de un obispo de la ciudad de Bolonia con sabor a leyenda y que, en el transcurso de dieciséis años del siglo XX, a lomos de su cabalgadura, se ha batido en una serie de victoriosas batallas que terminaron, al final, en una derrota épica.

El personaje que está en el centro de este acontecimiento es un sacerdote, de nombre Giacomo, hijo de Giuseppe Lercaro y de Aurelia Picasso, nacido frente al mar de Génova el 28 de octubre de 1891, ordenado sacerdote en 1914 y nombrado por el Sumo Pontífice, arzobispo en la sede de Bolonia en 1952 (Fig. 1).

Anticipemos ya, para que el público pueda introducirse desde ahora en la dimensión global de aquel momento histórico, que Lercaro, al asumir la dignidad episcopal de Bolonia en el momento de su pleno desarrollo demográfico y urbanístico de posguerra, se encontró con la necesidad de tener que hacer frente al problema acuciante de conseguir, en las áreas de nueva urbanización, los terrenos que habrían de acoger, con el tiempo, las futuras organizaciones pastorales en el territorio, antes de que la edificación comercial saturase todo el conjunto de parcelas (Fig. 2). Las cifras son ya, por sí mismas, significativas. En aquel periodo la ciudad crecía en veinticinco mil habitantes al año, y valorando el índice de 5000-7000 habitantes para cada parroquia, no sólo se deberían construir al menos tres o cuatro iglesias al año, sino que, ya para un lapso de tiempo limitado de veinte años, el número de parcelas que había que encontrar en las zonas de expansión era mucho mayor de sesenta. Esto es lo que Lercaro, en los dieciséis años en los que permanece en la sede de Bolonia, logra realizar, sin gravar las empobrecidas cajas de la curia, sino obteniéndolo directamente de los ciudadanos, según un proceso con garantía del cual hablaremos.

La historia es conocida. Pero yo la recuerdo y la anticipo para que la continuación del relato contenga, para todos los oyentes, la referencia final de la tragedia.

El 12 de febrero de 1968, Lercaro, después de un episcopado excepcional que logra arrastrar a la ciudad a un estado de entusiasta perspectiva de adhesión al espíritu cristiano y a la fe, fue obligado, por una maniobra subterránea de la curia romana, promovida por personajes reaccionarios de los cabildos de San Pedro de Roma y de San Petronio de Bolonia, a dejar su diócesis para retirarse a la vida privada. Pero, ¿cómo se puede llegar a una decisión tan grave y dramática que no tiene parangón en la historia de la Iglesia católica? ¿Qué llega realmente a realizar Lercaro en el lapso de tiempo tan limitado que se le concedió? Vayamos por partes.

Fig. 1. Giacomo Lercaro, arzobispo de Bolonia (1952/68). 


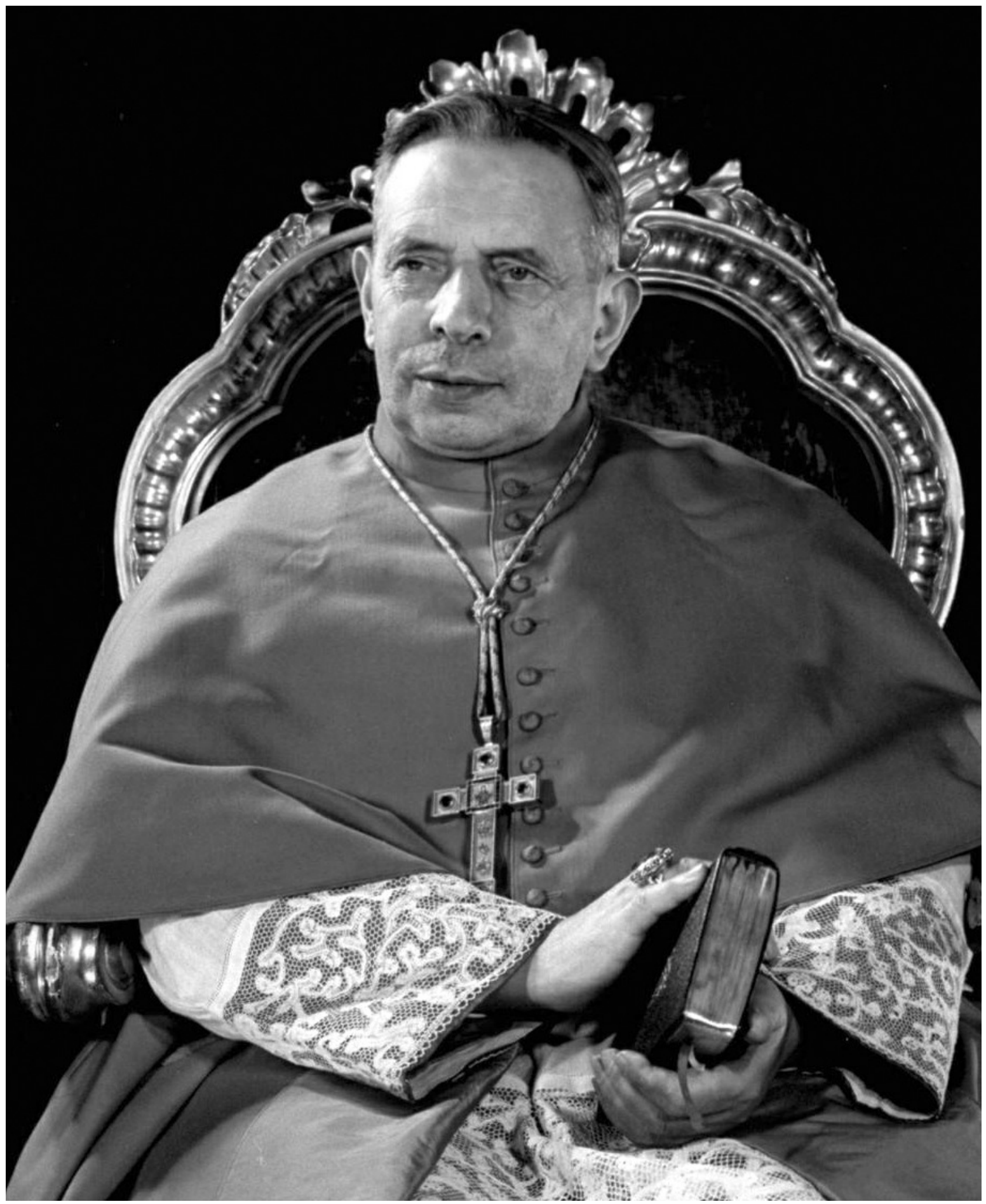




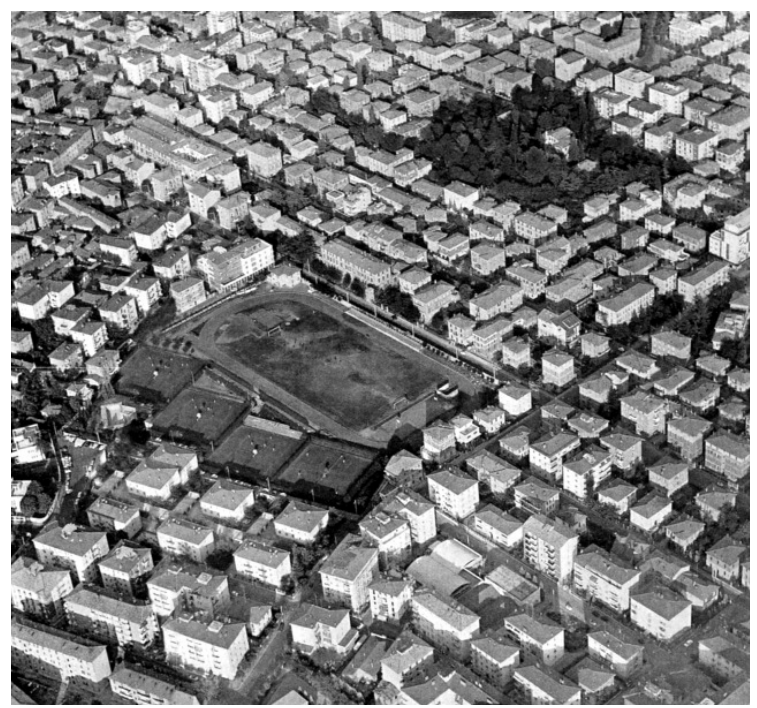

\section{EL DESCUBRIMIENTO DE LA MISA}

La vivencia boloñesa del cardenal Giacomo Lercaro no puede estar contenida tampoco en una enciclopedia; de las cosas que se puedan relatar, la mayoría quedará excluida. Históricamente, como moderador del Concilio Vaticano II (1), se sitúa como primus inter pares en la larga disputa conciliar sobre la promulgación de los principios de la reforma litúrgica; pero en paralelo, se erige como importante miembro del proceso de apoyo de la arquitectura moderna al camino que la liturgia estaba llevando a cabo. Su interés, su proximidad y, en suma, su confianza y declarada admiración hacia los principios propios de la arquitectura, no provenían de una tendencia natural ni de una cultura adquirida a través del estudio, sino que se materializaron a través de procesos y acontecimientos vividos como experiencias personales, de los cuales intentaré trazar hoy el curso de su gradual formación. Lo que requiere dar un paso atrás.

El pastor Lercaro vivía al máximo el misterio de la eucaristía como presencia viviente en la misa. Su primer texto, al llegar a Bolonia, es su opúsculo «A messa figlioli», donde los dos términos del binomio nos hablan ya de su preocupación de padre. La misa era para él verdaderamente el pan cotidiano, que vivía y compartía con los niños de su familia. Y la primera iglesia que se propone realizar es la de su residencia, en la
Fig. 2. Bolonia, años cincuenta. Expansión indiferenciada del tejido urbano periférico, con solares residuales para equipamientos entre el parcelario construido sede del arzobispado. De inmediato nos pide a Giorgio Trebbi y a mí diseñar — en una habitación — la disposición para la celebración comunitaria. Estamos a diez años del concilio, pero el diseño que yo realizo, y que se conserva en mi archivo, dispone un altar-mesa en el centro y bancos sin respaldo ni reclinatorio alrededor, como ovejas en torno a la fuente. Yo tenía entonces treinta y tres años, no tenía ninguna experiencia en arquitectura sacra, y sin embargo realicé aquel diseño, y con aquellas palabras se lo expliqué al cardenal.

La realización no llegó a término por los escrúpulos de Lercaro, que entonces pensó: «Y nosotros aquí, mientras que los hermanos de la periferia no tienen ni siquiera un lugar [de culto]». Pero la experiencia del qué y del cómo hablamos de aquel diseño, dejó en todos nosotros una profunda huella.

La celebración de Lercaro alcanzaba el sentido pleno de la participación, en el momento de la homilía. En aquel espacio de tiempo, Lercaro hablaba con el corazón y relataba la historia del misterio divino y de la verdad sacramental en forma directa, con una capacidad de expresión tan humanamente fraternal como para implicar a todos. Era como si hablando a todos, charlase directamente con cada uno, uno a uno, entre todos. Era magia comunicativa.

Si este era el ambiente dentro, las situaciones externas eran diferentes. Por supuesto que se celebraban ofi- 
Fig. 3. Situación catacumbal de la parroquia de San Vincenzo de Paoli en 1954. Exterior e interior
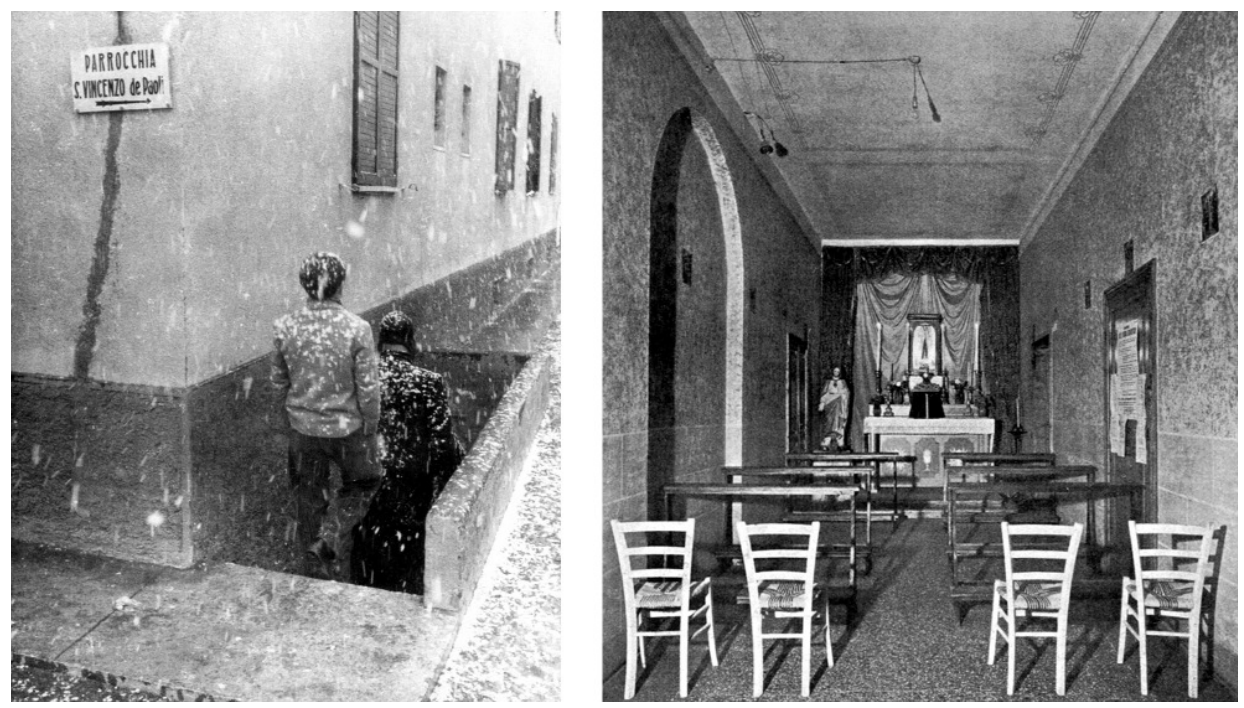

cios en las imponentes iglesias de la ciudad, en la catedral de San Pedro, en la basílica de San Petronio, en la basílica de los Servitas, en San Domenico y en Santo Stefano, donde el esplendor cortesano imponía una actitud formal. Pero el drama se manifestaba en las iglesias de la periferia construidas en el siglo anterior, con espacios alargados y con el altar olvidado al fondo, donde ni la luz, ni las proporciones, ni las dimensiones, ni la vivacidad de la materia, ni la disposición de los bancos, tenían ninguna relación con el oficio religioso que debía llevarse a cabo. Lercaro sufría las celebraciones en semejantes espacios con verdadera angustia. Porque él no podía ser, allí dentro, el que verdaderamente era. Porque no podía expresar, en un espacio tan insulso, lo que habría querido decir; porque sentía que su comunicación no llegaba a su destino y, en definitiva, porque sentía claramente que en aquellas estancias la cuncta familia era cualquier cosa menos una comunidad participativa y consciente. Como él habría de decir en múltiples ocasiones, salía abatido de tales experiencias.

Increíblemente, se comenzó a producir un conflicto clarificador con la preparación de soluciones provisionales, de las primeras iglesias de emergencia (Fig. 3). Para muchas de estas capillas improvisadas, Lercaro deseaba inmediatamente la constitución de la nueva parroquia y la asignación del párroco; yo había sido elegido como responsable de la parte técnica de la cons- trucción de nuevas iglesias, de realizar la disposición interior para la organización de la asamblea. Como mucho, con un altar de madera —versus populum naturalmente, con un anticipo de diez años a la promulgación de los principios de la nueva liturgia conciliar-y con bancos agrupados en racimo en torno a la mesa pero con un cierto sentido poético de control de la luz natural, se lograba una espacialidad interior viva, como regulada por la energía que se concentraba en el altar.

Estas soluciones, por lo general en espacios pequeños o muy pequeños (un garaje, un piso, una tienda, un sótano), con el crucifijo de pie al alcance de la mano, que casi parecía uno de los asistentes, con el cuenco de hierro esmaltado donde estaban las sagradas formas que los fieles, según iban llegando, cogían y colocaban en la píxide para la consagración, construían la primera familia en Cristo.

Era con los oficios en estos espacios improvisados, dotados de una poesía minimalista, en contacto directo con los fieles, con los que Lercaro volvía a ser el padre. Sus palabras encontraban el timbre entusiasta de la verdad proclamada. ¡Y su rostro expresaba de nuevo el sentido de la alegría! Y él salía al exterior radiante.

Este baño salvífico, en los espacios que, en su primitiva sencillez, contenían el signo de aquel espíritu moderno que nuestros arquitectos perseguían como imperativo categórico, contribuyó de modo fundamen- 
tal a hacer evidente al cardenal Lercaro cómo la celebración en la versión de la nueva liturgia - todavía no oficializada por el Concilio aún por venir- necesitaba de un espacio nuevo, ausente en las iglesias de épocas antiguas, y que sólo se le podía demandar a la arquitectura moderna. Parecía cada vez más evidente que el principio de interrelación entre los contenidos del nuevo planteamiento litúrgico y la forma del espacio de la celebración se convertía en algo necesario e imprescindible.

La liturgia persigue el fin de hacer comprensible la verdad trascendente por medio de imágenes simbólicas en la forma y en los hechos, principios abstractos que sólo se materializan con la estructuración física perceptible aportada por el espacio. Pero quien hace que el espacio sirva a la liturgia es la arquitectura. El espacio no existe si no es a través de la arquitectura.

Liturgia, espacio simbólico, arquitectura: sólo en esta secuencia se obtendrá la realidad del espacio místico de lo sacro. Sólo cuando la arquitectura presta este servicio de modo mágico, logra la liturgia expresar todo su valor icónico, se presenta en toda su fuerza simbólica y llega a ser vehículo de trascendencia. Cuando tenemos la fortuna de visitar una iglesia en la que esta sinergia se haya podido realizar, vivimos una experiencia única al descubrir cómo los gestos y contenidos litúrgicos se mantienen, se conectan y se representan a través de la irradiación del espacio arquitectónico.

Por eso Lercaro, cuando tuvo que debatir en el seno de la comisión conciliar para la coordinación de los trabajos en materia litúrgica, además del tesoro de su conocimiento científico y de su fe, llevaba consigo el entusiasmo de las experiencias vividas en las celebraciones. En ese momento, en las primeras fundaciones comunitarias, y luego, en las nacientes iglesias nuevas, pudo decir: ¡Lo conozco porque lo he visto; lo sé porque ya lo he experimentado!

\section{CONSTRUIR UNA IGLESIA COMO TESTIMONIO DE AMOR}

Lo que hacía de Lercaro un gran pastor era su comprensión de la acción pastoral y litúrgica, vivida sobre todo a través de la misa - y la homilía - como instrumento de salvación y de servicio del hombre, no sólo para su redención cristiana, sino para su propia dignidad y valoración humana. Para Lercaro, el problema humano y espiritual era directo y concreto. Él estaba animado por una preocupación hacia aquellos hombres, aquellas familias, aquellos muchachos, aquellos trabajadores que estaban en aquel sitio concreto, en aquella parte de la ciudad, en aquella zona que tenía una situación ambiental propia, bien definida, originada por aquella calle, aquella fábrica, por aquel árbol.

Y dentro de la atmósfera de una sensibilidad parecida, que individualizaba cada pequeña porción de la ciudad como espacio en el cual debiera tomar cuerpo una comunidad activa y recíprocamente partícipe, el Ufficio Nuove Chiese (Oficina de nuevas iglesias) pudo conformar el primer plan de servicios de la ciudad de Bolonia. La intención, transferida al plano, era la de que aquellos hombres y aquel trozo de territorio recibiesen los medios para que su existencia cotidiana pudiese ser más auténtica, más completa y más partícipe de un significado espiritual de su propia época...

Las intervenciones que han conducido a la construcción de más de sesenta iglesias pueden todas ellas ser leídas como intuición paterna, e instante de amor con el que el pastor ha pensado en aquellos hijos, como dilatándose espiritualmente hasta cogerlos entre sus brazos; procediendo de modo que no sucediese que ellos estuviesen allá y en cambio otros —incluido élestuviesen acá; para que nosotros tuviésemos el signo del Señor y ellos no fuesen privados de él.

Baste sólo un recuerdo entre tantos. En la zona de Casaglia, ante la angustia de que los hermanos pudiesen sentirse ignorados y que les faltase el consuelo de participar en la vida litúrgica, Lercaro nos animó a actuar con empuje para que no se perdiese un solo minuto de su preciosa vida (2). He aquí ya una sede, aunque pequeña como una habitación, pero no desprovista del signo litúrgico de un proyecto que quedará como emblemático (Fig. 4). Y ahora, como referente y partícipe, don Walter Michelino. Lercaro se priva de su mismo secretario personal como un padre que envía a su hijo mayor en ayuda de los más pequeños. Y don Walter oficia enseñando a los fieles la posición erguida digna del hombre - también adecuada a un espacio tan estrecho-, en una liturgia tan verdadera y tan marcada por lo cotidiano - por lo real y por lo fraterno- como para dejar, en todos los afortunados que lo disfrutaron, el recuerdo de un instante de poesía inalcanzable en otro lugar. En aquellos días, esos hombres no estuvieron solos y realmente llegaron a ser una familia; y el lugar de encuentro crecía sencillamente con ellos, 


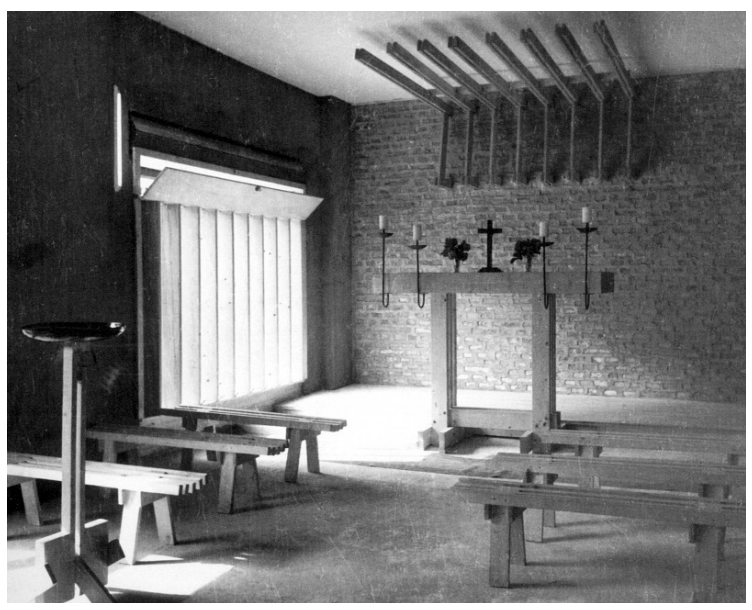

Fig. 4. Glauco Gresleri, habilitación provisional de un garaje como iglesia parroquial en Casaglia (Bolonia, 1956); interior.

pasando del garaje (con las ventanas apantalladas con tablas de madera para que la luz de la onda luminosa se convirtiese en instrumento de poética expresividad) a la solución de hoy - roja por fuera, como la misma idea de ciudad, y blanca por dentro, como lugar de luz, de verdad y de alegría-, convirtiéndose en verdadero espacio común, en el referente familiar en esta parte de la ciudad; estructura/forma que en la emergencia arquitectónica de la iglesia ha encontrado una significación definitiva (Fig. 5).

El signo de la gran intuición lercariana al emprender el camino tan difícil del construir se convirtió entonces en testimonio de amor. Nada se hace por hacer, nada se mueve para realizar la obra como un fin en sí misma. El construir no tiene programa formal ni voluntad histórica. Las reglas académicas no tienen valor en sí mismas. Cada cosa nace para servir. El modo de hacer las cosas es sencillamente el del respeto, la atención y la sensibilidad hacia los que utilizarán los instrumentos y hacia aquel sector de la ciudad. «El modo de construir es signo y ejercicio de amor», titulará, treinta años después, Giovanni Catti, una de sus ponencias en el simposio de arte sacro de Verona en 1989, recogiendo con gran intuición el profundo significado del trabajo de aquellos espléndidos años. El amor y el respeto hacia la comunidad parroquial era el primer y verdadero acto del proyecto. Organización,

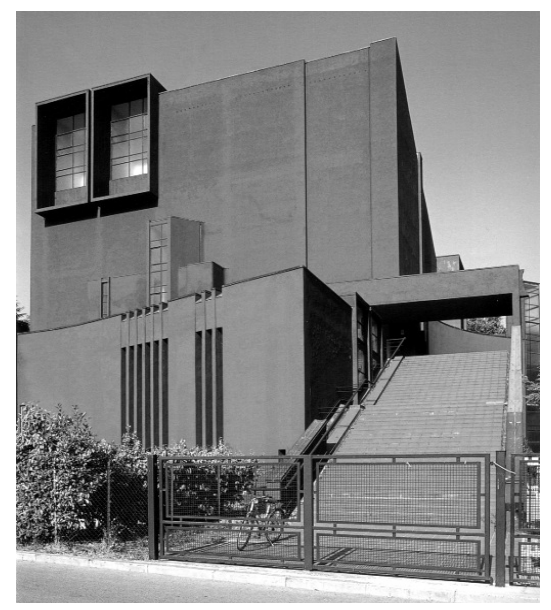

Fig. 5. Luciano Lullini, iglesia parroquial de Sant'Eugenio papa en Casaglia (Bolonia, 1963/73).

distribución, forma, la misma intuición litúrgica de la participatio actuosa, la globalidad e interacción de los momentos sacramentales, todo debía de conseguirse con tal de que el primer movimiento se produjese en la transfiguración a través de la humildad de la propia atención hacia la presencia diversa de los otros, en aquel preciso lugar.

Y nada más. Sobre todo, nada de inútiles batallas sobre las formas. Nada que fuera prefijado y codificado. El programa, la solución, la planta, la arquitectura, nada estaba determinado ni convenido, todo estaba por encontrar y descubrir. La disciplina arquitectónica debía dar libertad de movimiento, tras momentos e intuiciones dictados por la realidad objetiva e histórica. La praxis del Movimiento Moderno en arquitectura, es decir, la elección de la única verdad disciplinar posible en el momento histórico - el famoso linguaggio dei vivi (lenguaje de los vivos)-, liberaba para siempre de la esclavitud de viejas formas y expresiones, ahora modelables para una nueva vida litúrgica entre los hombres y el Misterio.

Este ha sido el momento increíble de la época lercariana: haber podido creer en la aportación de tantos; la colaboración de personajes de gran relevancia - inicialmente ignorados y excluidos-; el recurrir metódicamente a las disciplinas de la urbanística y de la arquitectura, de la sociología y de la liturgia; las clases para 


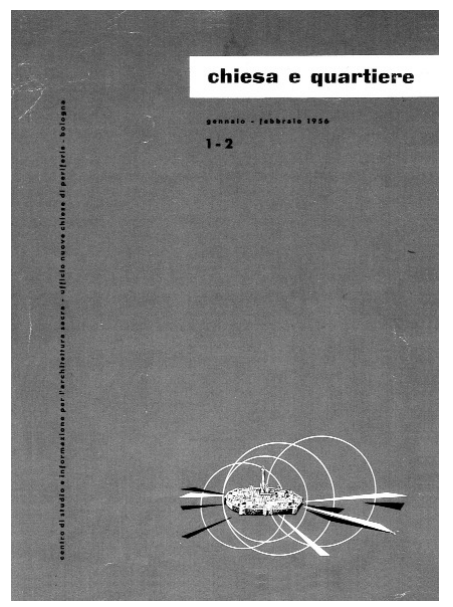

Fig. 6. Portada del número 1-2 (1956) de la revista Chiesa e Quartiere.

dar y recibir; los estudios y debates a través de las más de cinco mil páginas de Chiesa e Quartiere (Fig. 6); el considerar que todo esto fuese el paso necesario no para llegar a un modelo codificado, sino solo para poder estar disponible para el evento proyectual; poderse dedicar con la pureza de corazón del niño y con la sensibilidad del poeta a la atención de los casos individuales, para intentar conseguir para cada uno de ellos la invención del lugar, y materializar el momento espacial único y completo que llegase a conjugar la religiosidad de los hombres con la del emplazamiento, haciéndola reconocible.

Esta fue la inspiración de Lercaro: la de imaginar la ciudad como reserva de una inagotable posibilidad para rescatar de la pobreza los ámbitos de una periferia no diseñada, a través de una continua carga de espiritualidad que, en primer lugar, trabajase con una actividad de orden urbano y arquitectónico.

Estaba claro para él que las estructuras pastorales debían ser diversas. Diversas: como, según se habría podido definir, más abiertas, alegres, iluminadas, capaces de transmitir emociones, en las que fuese fácil y agradable entrar, encontrarse, cantar, escuchar, mirar, participar, ¡orar! ¡Qué mundos sublimes se podrían imaginar, donde la palabra de Dios y la acción santificante de la Eucaristía pudiesen liberarse como acto de alegría privada y colectiva, y donde la iglesia pareciese realmente la casa de cada uno! Rica para los que tenían una morada humilde, luminosa para aquéllos que vivían en zonas umbrías; espaciosa para quien desease la sensación del aire libre; ijoven para unos y otros! Si la Iglesia debe hablar de salvación en la eternidad, entonces la iglesia construida debe al menos hablar de liberación de situaciones infaustas, liberación de los espacios turbios y aburridos, liberación en el intercambio del signo de la paz, en plena luz gozosa. Esta fue la relación que Lercaro llegó a desarrollar con la arquitectura.

\section{LA PACIFICA CONQUISTA DE LA PERIFERIA DE BOLONIA}

¡Ciertamente hubo un comienzo! Cuando, en 1955, Lercaro planea realizar un congreso sobre música sacra, por consejo del arquitecto Giorgio Trebbi, y considerando que, por encima de otros temas de orden cultural y espiritual, el espacio destinado a lo sacro tiene un valor decisivo, cambia el objeto del simposio, llegando a convocar el gran I Congresso Nazionale di Architettura Sacra (1955). A partir de aquí, al afianzarse en su convicción sobre el principio de la modernidad como instrumento pastoral, el paso fue corto y completo. Los alicientes, los ánimos que le llegaron de inmediato - ya en 1954 - del arquitecto Giuseppe Vaccaro y del arquitecto Giorgio Trebbi, en verdad lo confortaron, pero fueron semillas que cayeron sobre un campo ya labrado y próximo a dar sus frutos.

Esta era entonces la tarea. Este era el mandato que Lercaro dio al grupo de jóvenes voluntariosos que, de forma no expresa, probarían la propia capacidad profesional mantenida por el triple aporte de mente, corazón e inteligencia, al servicio de esta batalla de conquista. ¿Conquista de qué? De las mentalidades no preparadas para saber ver las maravillas de la planificación moderna, y que todavía concebían el edificio eclesial como obra constructiva, y no como instrumento que debía convertir en verdadera a la liturgia, haciéndola reconocible.

Pero la idea de Lercaro iba más allá. Él creía que las nuevas áreas de asentamiento de la ciudad tendrían necesidad sobre todo de la creación de emplazamientos dotados de identidad de lugar, en grado suficiente para transmitir a sus habitantes una consciencia humana y habitacional; porque aquellos jirones habitados transformados en porciones de ciudad, habrían contribuido a transformar a los residentes en comunidades capaces de 


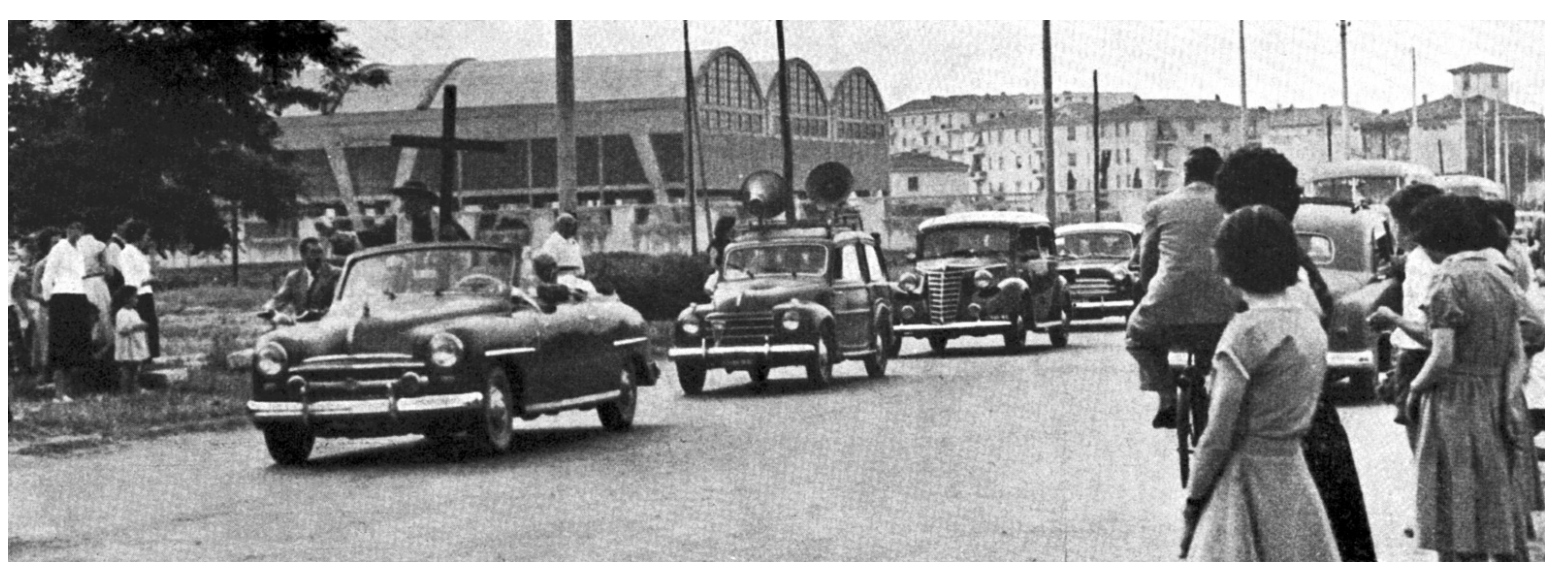

Fig. 7. Lercaro, de pie en un coche descapotable y abrazando una gran cruz de madera, recorre la periferia de Bolonia seguido por una comitiva de fieles (26 de junio de 1955).

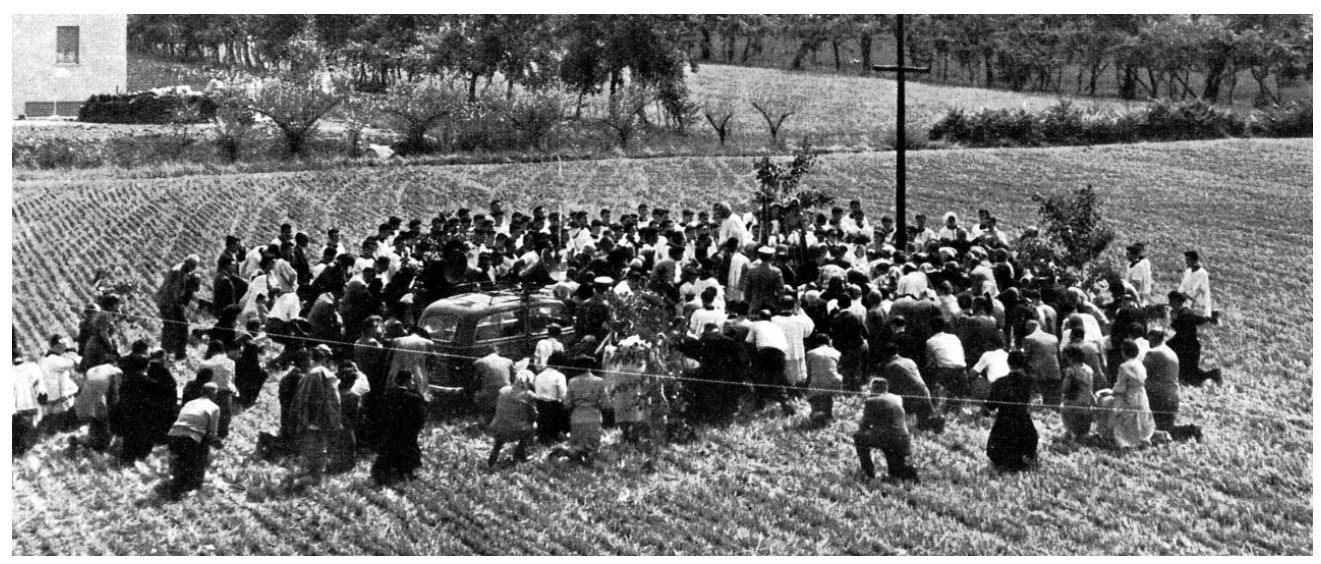

Fig. 8. La cruz de madera en la periferia señala el solar adquirido para una nueva sede parroquial (1955).

Fig. 9. Parroquia de Santa Rita de Casia; cortijo adaptado como lugar de culto (1955).

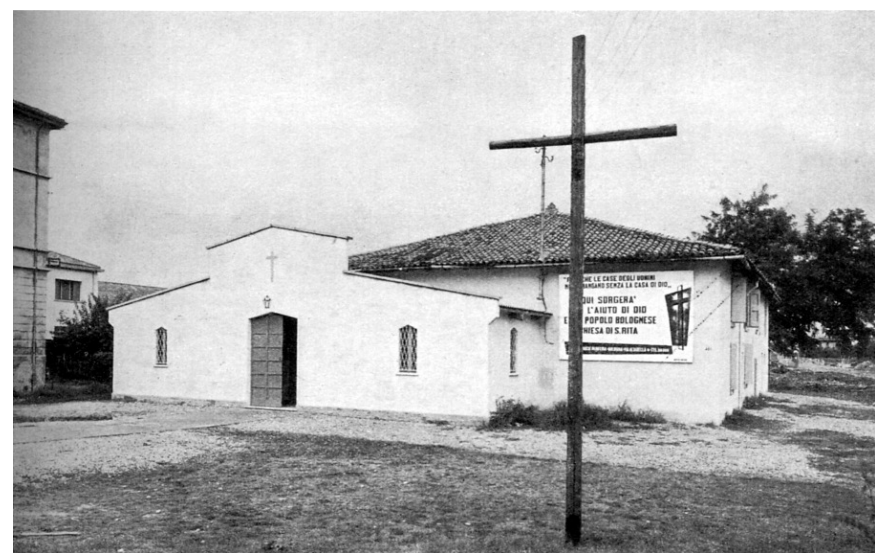


autogenerarse como consciencia urbana. Y entonces, ¡he aquí el anuncio oficial dado por Lercaro, durante un sermón dominical, de querer emplear sus energías en la pacifica conquista evangélica de la periferia de Bolonia!

Las operaciones materiales tuvieron su inicio concretamente el 26 de junio de 1955, cuando el arzobispo, de pie sobre un coche descapotable y abrazando una gran cruz de madera, precedido por un policía en motocicleta y seguido por una comitiva de coches de incondicionales, recorre la periferia urbana deteniéndose brevemente en once parcelas ya comprometidas para la realización de las nuevas sedes parroquiales donde, al lado de un gran crucifijo plantado en la tierra desnuda, un cartel portaba la significativa leyenda: «Qui sorgerá con l'aiuto di Dio e del popolo bolognese la chiesa del...» (Aquí, con la ayuda de Dios y del pueblo boloñés, surgirá la iglesia de...») (Fig. 7-9).

El pastor había dejado su trono; desde su palacio real había abandonado el centro — cerrado y autoprotegido en su conservadurismo social y religioso como una isla ya sorda - y se había lanzado a la conquista de una ciudad desconocida — la segunda Bolonia, como él la llamaba-, no proyectada ni objeto de cuidados por parte de nadie. Hace medio siglo que Lercaro se dio cuenta de que ésta era la verdadera ciudad que debía de ser objeto del proyecto; que su crecimiento no tenía que ser en número, sino en calidad; iy que su evangelización no podía ser llevada a cabo si no se hubiera podido reestructurar su urbanismo, su naturaleza de estructura para los hombres!

Estuvo claro desde el principio que el término iglesia invocado en aquellos grandes carteles, no se limitaba al objeto construido ni a la sede material de la parroquia, sino que comprendía un programa más vasto y ambicioso: el de conformar realmente la Iglesia de los hombres a través de la construcción de la ciudad de los hombres. Zona de nueva urbanización sin estructura reconocible de ciudad, de pobre calidad ambiental, lugar de diversos grupos con orígenes muy diversos, de gente o bien aplastada bajo la losa del estalinismo o bien encerrada en una comprensible defensa dentro de un sucinto anticomunismo ideológico internacional, la periferia fue objeto de una atención imprevista e inimaginable.

Esta predilección de Giacomo Lercaro por los bordes descuidados con respecto a las estructuras consoli- dadas — incluso eclesiásticas - del centro, (que le ocasionó graves divergencias en el seno de la Jerarquía, con las consecuencias finales de su gran derrota), sólo era comparable a la relación de una madre con el hijo más débil, y se reorientaba hacia la similitud de la relación preferente, citada en la Sagrada Escritura, de Dios para con los pobres. Contra la indiferencia y la secularización de los nuevos asentamientos urbanos, Lercaro mostró una lúcida y rigurosa determinación, comprendiendo cómo la acción pastoral habría podido surgir sólo de una obra real de evangelización e inculturización eclesial, y que ésta sólo habría podido tomar fuerza sostenida al mismo tiempo por varias partes y con todas las armas posibles. Así que realiza esto (continuando con nuestro juego de similitudes), no sólo utilizando las tropas de infantería - representadas por el párroco establecido en el lugar-, sino recurriendo a fuerzas especiales combinadas, como las de la formación catequética, las de la misión pastoral, y sobre todo, las concernientes a las obras arquitectónicas para el despliegue de la vida litúrgica. Era impensable, según Lercaro, establecer nuevas comunidades si no se había procedido primero a su preparación y a su formación. Visto a una distancia de cincuenta años, aquel proyecto general aparece como increíblemente coherente y preclaro.

Anticipando en treinta años la intuición del papa Juan Pablo II que, con el fin de establecer la relación que une la obra de evangelización en el mundo con el arte sacro promueve en 1988 la Pontificia Comisión para los Bienes Culturales de la Iglesia, Lercaro ya había comprendido el valor insustituible de la arquitectura dentro de su gran plan. Sería inútil -e incluso dañino - un edificio eclesial que fuese pobre (en calidad poética), y mal hecho (por incoherencia litúrgica); un delito de despilfarro contra el pueblo, contra el espíritu de evangelización, contra la labor pastoral iy contra Dios! Todo podía y debía ponerse ab initio para que el volumen fuese un punto clave del contenido urbano, por llenarse de significado cívico y de vitalidad humana.

Estaba claro cómo la iglesia de piedra debía asumir el cometido, con respecto a la ciudad, de transformar su trama en potenciales barrios. ¿Que momento, qué época, cuánto ardor y entusiasmo, qué coincidencias, qué generosidad contagiosa por la cual todos pensábamos en dar, y ninguno en tomar! ¡Qué crisol de preocupaciones fue el Centro de Studio e Informazione per 


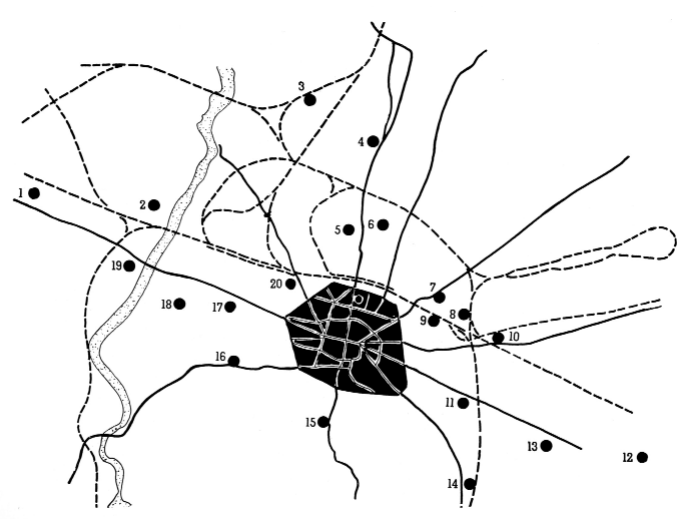

Fig. 10. Ubicación de las nuevas sedes parroquiales en la periferia de Bolonia (1955).

l'Architettura Sacra de Bolonia! Si la sección técnica del Ufficio Nuove Chiese fue el brazo secular del movimiento, es cierto que el Centro de Studio fue fragua internacional de valores inestimables. Fundado el 7 de octubre de 1960 bajo la presidencia de Lercaro, la dirección de Trebbi y yo mismo en la administración, delegando en monseñor Luciano Gherardi para la dirección de la revista Chiesa e Quartiere, el Centro llega a ser en poco tiempo un lugar de pensamiento que acumuló en su labor una fuerza interdisciplinar de importancia universal. Es imposible recoger los nombres de cuantos participaron y contribuyeron con sus ideas. Entre los más asiduos y entre los defensores se incluyen nombres carismáticos de nivel mundial; arquitectos, artistas, pero también pensadores, filósofos, escritores y sacerdotes. ¡Y no solo europeos, africanos y americanos, sino también orientales, rusos y chinos!

\section{LA GESTIÓN URBANÍSTICA: IGLESIA Y BARRIO}

Pero, ¿qué sucedió realmente durante aquellos trece años de entusiasmo, que van desde el torbellino de junio de 1955 hasta el alejamiento forzado de Lercaro del solio arzobispal en febrero de 1968? Es difícil hacer un balance, porque a menudo se mezclan hechos concretos y reales con acciones y conexiones en el plano de las interrelaciones no fácilmente catalogables.

Pero si el resultado citado en la realización de nue-

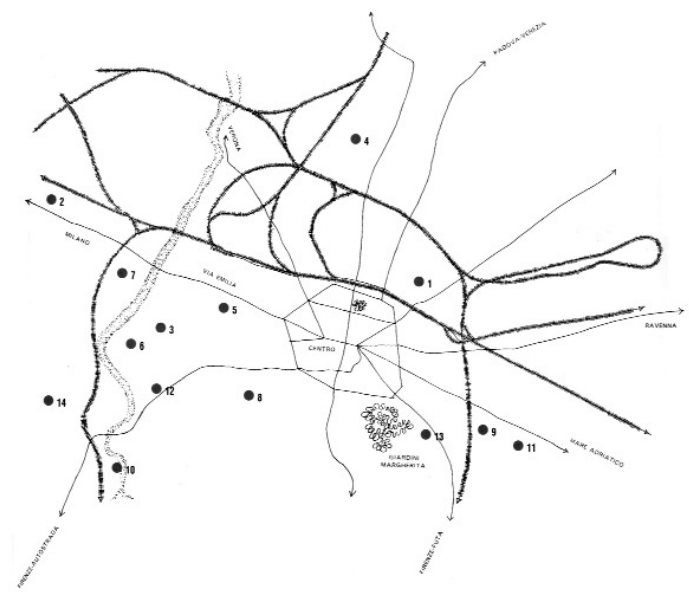

Fig. 11. Iglesias finalmente realizadas por el Centro Studi (1968).

vas iglesias tuvo límites importantes - porque frente a los pocos casos que Lercaro llega a proponer personalmente a un arquitecto, la curia, sustrayéndose a las directivas del arzobispado e indiferente ante la nueva búsqueda litúrgica, favorecía la selección de profesionales que practicaban una tipología simplificada de sello novecentista-, bien distinto se presenta el balance del trabajo desarrollado en la planificación para la adquisición y recalificación de las zonas de futuras dotaciones de tipo religioso, a través del Plan de Servicios. Se trabajó en la identificación cartográfica de las zonas todavía libres de construcciones respecto a las mallas residenciales, para que —en tiempo real- se pudiese valorar su posible utilización para usos tanto de tipo religioso como para anexos con instalaciones educativas y sociales. Con un exhaustivo y escrupuloso examen del Plan General Regulador de Bolonia, el resultado de reservar para las dotaciones de tipo religioso las zonas necesarias, en posición congruente con la malla urbana, se logró en casi todos los sitios (Fig. 10 y 11).

En estos planes trabajó un gran número de arquitectos por propia y libre iniciativa, sin compensación ni remuneración alguna, demostrando una disponibilidad profesional digna de todo respeto, y signo del clima de mágico entusiasmo que se respiraba en los ámbitos sensibles de la profesión, conquistados por el carisma del 
arzobispo. Fue una inversión cultural y técnica de importancia básica, y que permitió al arzobispo auxiliar, monseñor Gilberto Baroni, moverse con seguridad y determinación en la definición de las fases de adquisición de los terrenos. Si la planificación de la oficina hubiese faltado, los plazos, las soluciones y los costes se habrían multiplicado, convirtiendo el plan de reconversión de la periferia en algo absolutamente inalcanzable. Mientras tanto, las siguientes gestiones arzobispales encontraron el problema de la planificación pastoral ya resuelto. Pero, ¿cómo era posible la adquisición inmediata de un terreno sin recursos financieros?

El arzobispo tuvo la idea de implicar la libre iniciativa de las instituciones ciudadanas dentro de una entidad, Casa di Dio (Casa de Dios), estructurada como sociedad anónima. Ésta le da un respiro a la diócesis, interviniendo, con el dinero de los accionistas, en la adquisición directa de las parcelas localizadas por la sección técnica de la oficina, poniéndolas a nombre de la sociedad misma para que permaneciese cubierta financieramente por el desembolso realizado. Después, cuando la parroquia constituida estaba en situación de hacerse cargo directamente de la titularidad del terreno, el cambio se llevaba a cabo sin recargo de intereses, y la sociedad podía reembolsarse las participaciones respectivas. La sociedad Casa di Dio, operando con la máxima tranquilidad financiera para que la fluctuación de precios que las parcelas estaban sufriendo con el crecimiento de la periferia, se conformase poco a poco como cobertura real del riesgo de anticipo, hizo posible la operación de constitución de todo el parcelario.

Pero el fin último no era la iglesia a secas: era la iglesia en el barrio - Chiesa e Quartiere, cabecera de la revista convertida en emblemática-, y el proyecto avanzaba paritariamente en dos frentes: arquitectura moderna para la verdad litúrgica, y transformación en barrios de las mallas urbanas sin calidad. iQue clarividencia en la intuición de las transformaciones sociales que habrían de cambiar la ciudad, como ahora comprobamos día a día! En Colonia, en el aula magna de la gran universidad alemana, invitado por aquel consejo académico en 1968, Lercaro expone su tema «La Iglesia en la ciudad del mañana» imaginando la desaparición de la ciudad clasista — que se daba en Bolonia, en la dicotomía entre centro y periferia, incompatible con el mensaje cristiano - para preparar un terreno propicio para la integración entre gentes de diversas extracciones, razas y tradiciones mediante una participación que permitiese a la comunidad espiritual de la Iglesia experimentar conjuntamente con el mundo la misma suerte terrena. Lercaro no se quedó en el plano de la teoría, y desde que se le concedió el solio episcopal de Bolonia, trabajó en sentido estricto por su ciudad.

\section{EL PACTO ENTRE LA IGLESIA Y LOS ARTISTAS}

El gran proyecto que el 15 de agosto de 1964, día de la Ascensión, llevó al papa Pablo VI a sellar en la Capilla Sixtina — delante del Juicio Final de Miguel Angel - el pacto entre la Iglesia y los artistas cuyo texto comenzaba: «Os necesitamos...», fue realizado por Lercaro, concretamente a través de los grandes momentos que verán a la ciudad dialogar con personajes del Gotha arquitectónico internacional. Me refiero naturalmente a Alvar Aalto, a Le Corbusier y a Kenzo Tange. Esta acción de apertura e implicación a escala internacional, de la cual se han dado varias interpretaciones a menudo distorsionadas, se lee según dos aspectos integrados entre sí. En primer lugar, la preclara intuición de no dejar terminar el siglo sin haber adquirido para la Iglesia cristiana el mensaje artístico de los máximos exponentes de la disciplina arquitectónica. Es imposible pensar que pudiesen desaparecer hombres de tan alto carisma artístico sin que la Iglesia universal les hubiese solicitado entrar en el grupo de nombres que han dado a la cristiandad el valor terreno de su imagen construida. Y, en segundo lugar, de modo contextual, el rescate de la periferia con obras de gran valor simbólico. Su amor por la ciudad de los pobres (ipobres sobre todo con respecto a la calidad urbana!), le hacía imaginar que la nueva Bolonia - frente al centro histórico saturado de edificios y espacios muy significativospudiese volver a formarse también como lugar de grandes signos, de nuevos iconos arquitectónicos capaces de irradiar energía vital a los barrios periféricos.

Cuando Lercaro conoce personalmente a Alvar Aalto, en Florencia, en la exposición de la obra completa del arquitecto y le pide - a él, conmovido como un escolarcillo - trabajar por Bolonia, no piensa en llevarlo hasta una ubicación importante, sino que lo destina a los límites extremos de la diócesis, en una localidad dispersa entre montes y ríos, al servicio de una comunidad que se sentía olvidada por la jerarquía eclesiástica (Fig. 12). La futura gran obra es situada de este 
Fig. 12. Alvar Aalto muestra al cardenal Lercaro la maqueta de la iglesia que será edificada en Riola di Vergato.

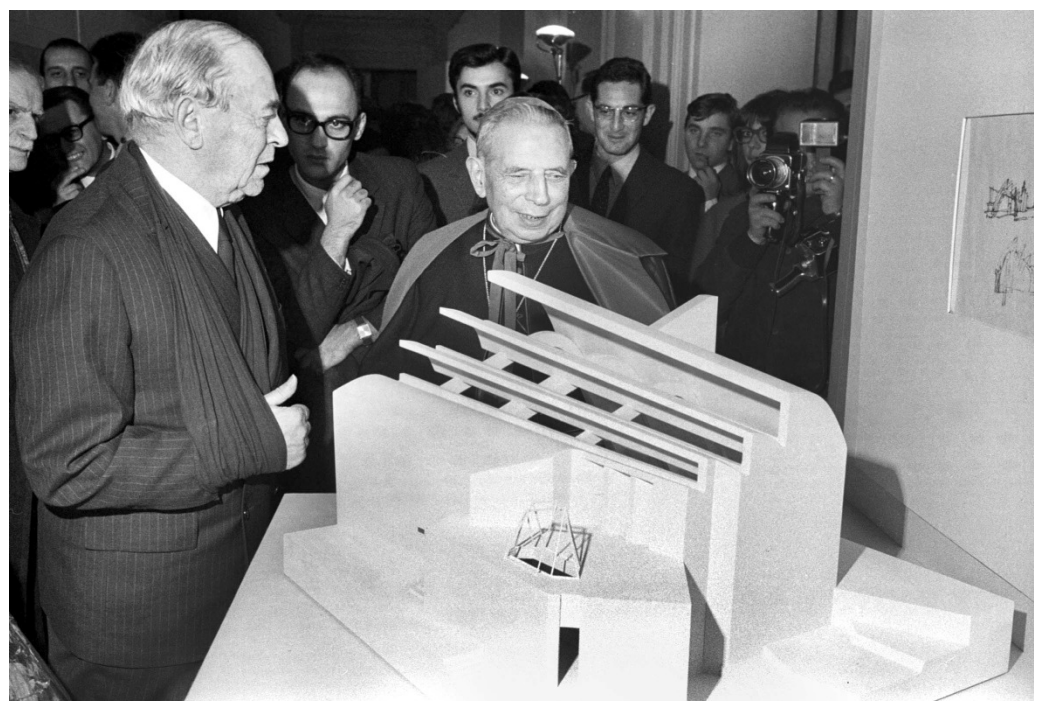

modo por Lercaro entre los ríos Reno y Limentra, al servicio de la comunidad de Riola, para que llevase a aquel lugar, así diferenciado del centro de la diócesis, un signo que iluminase con valor poético el valle.

Y a Le Corbusier, que a la solicitud de Lercaro de comprometerse en pro de una iglesia boloñesa responde: «Eminencia, ¿por qué me pide una cosa tan hermosa ahora que estoy tan cansado?», Lercaro le contesta: «Maestro, he reservado para usted, relevante arquitecto, el lugar que más hace falta en su obra: una zona desheredada, el barrio de la Beverara, tan olvidado por la ciudad y de tan poca calidad, que requiere una gran carga de poesía como regalo para la vida de aquellos hombres» (Fig. 13). Y aquellos hombres, reunidos en la junta de barrio, ante la noticia de que su obispo los aprecia tanto en su corazón como para destinar la construcción que habría debido ser la del siglo a su barrio para hacerlo resurgir con nueva vida, se quedan asombrados y conmovidos, y a través del teniente de alcalde envían una carta de aceptación y agradecimiento por la histórica designación.

E incluso el encuentro y posterior encargo a Tange se considera como el acto más previsor de un gobernante local en todo el siglo XX. Frente a la expansión como mancha de aceite de la urbanización periférica de Bolonia, que ya había edificado los sectores este y oeste, la administración municipal, a mediados de los años sesenta, anuncia el programa de un importante desarrollo al nordeste de la ciudad, sobre la prolongación del puente de Stalingrado, zona todavía parcialmente rural. Lercaro, con intuición urbanística, imagina que una intervención tan amplia no podía realizarse según las indicaciones de un plano técnico, sino que sólo un gran proyecto es capaz de rescatar aquella parte de la periferia y que puede hacer de ella la segunda Bolonia. Como planificador, contempla una ciudad en la cual la ordenación, la organización, la circulación, los espacios verdes, los lugares de encuentro y, en una palabra, la calidad urbana y su imagen respectiva, proporcionan al asentamiento y a la actividad de los hombres, la calidad poética y la alegría de vivir necesarias para su crecimiento material y espiritual.

En 1966 - han pasado sólo once años del momento cumbre del gran I Congresso Nazionale di Architettura Sacra en Italia del 23 de septiembre de 1955 que había dado paso a la profunda transformación cultural de Bolonia-, se encuentra con Tange y le ofrece proyectar una catedral ecuménica a situar en el centro de lo que será el nuevo gran asentamiento urbano (Fig. 14). Y con magnífica intuición, al darle sentido a la idea arquitectónica, cita el término cesto para indicar una forma reconocible donde, en lugar de varias clases de fruta, se encuentran hombres de extracción, cultura, raza, etnia, lenguas y colores diversos, todos ellos des- 


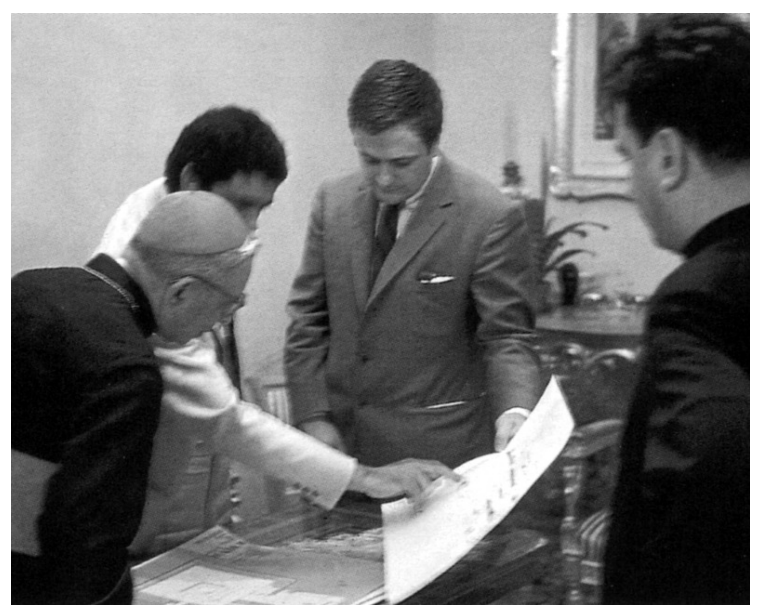

Fig. 13. El cardenal Lercaro, Guillermo Jullian de la Fuente, Jose Oubrerie y Luciano Gherardi comentan el proyecto para la iglesia del Hospital de Venecia y la situación planimétrica de la iglesia de Le Corbusier para Bolonia (septiembre de 1965).

lumbrados por la luz de una arquitectura que señala realmente la transición hacia «una época de paz y de verdadera integración entre las gentes».

Y, recibida la respuesta afirmativa de Tange —el gran urbanista proveniente de las experiencias del mikado - Lercaro va más allá, e imagina que él puede difundir la magia del proyecto del cesto por todo el barrio, por el mismo sector de la ciudad. Y es por ello que hace partícipe y promotor al alcalde Fanti (que intuye el salto de calidad que puede lograr Bolonia) para que la administración municipal decida confiar al famoso arquitecto el encargo del plan para el desarrollo de dicha parte de la ciudad.

Fue un momento de gran entusiasmo, de esperanza, de verdadera conmoción urbanística como nunca había sucedido con los diversos planes de Bolonia. ¡El plan, completado con una maqueta que incluía la colina, el centro histórico, la periferia, la llanura y el nuevo asentamiento, hermoso como un modelo decimonónico y vivo como un proyecto de futuro, le pareció una maravilla a todo el mundo! Pero de estos tres grandes proyectos sólo el de Aalto pudo llegar a concluirse. Los otros dos se sumergieron en las nubes tormentosas que comenzaron a condensarse sobre la cabeza del gran prelado, respecto al cual el drama que se consumó sobre la cripta de San Pedro resulta enormemente significativo. Frente a su gran visión de la ciudad, Lercaro quería, en concreto, una señal precisa acerca de la relación liturgia/arquitectura, ligada a un contexto histórico.

\section{LA CRIPTA DE LA CATEDRAL DE BOLONIA}

A la vuelta de la larga temporada romana como moderador del Concilio, y en conmemoración y signo del principio de la nueva liturgia que había recibido en el Concilio el derecho a expresar su vitalidad celebrativa, Lercaro pensó en realizar la primera obra en línea con la nueva constitución litúrgica, precisamente para la cripta de la catedral. Intentando expresar con esta obra la doble verdad de la liturgia participativa, y la necesidad de que también los espacios de sacralidad históricamente apropiados debían encontrar soluciones compatibles con lo preexistente y transformadas por el espíritu de la nueva consciencia litúrgica. Mediante decreto arzobispal, Lercaro sancionó el proyecto de reestructuración litúrgica de la cripta, llamando al grupo de Chiesa e Quartiere compuesto por Giorgio Trebbi, Giuliano Gresleri, Franco Scolozzi, don Angelo Raule (funcionario honorario de la Soprintendenza) (3) y yo mismo, bajo la guía de monseñor Luciano Gherardi. La dirección de la intervención fue ejemplar, y la nueva cripta fue inaugurada solemnemente el 12 de febrero de 1966 (Fig. 15 y 16). La obra está bien documentada en el número 37 — de marzo de 1966- de Chiesa e Quartiere. 


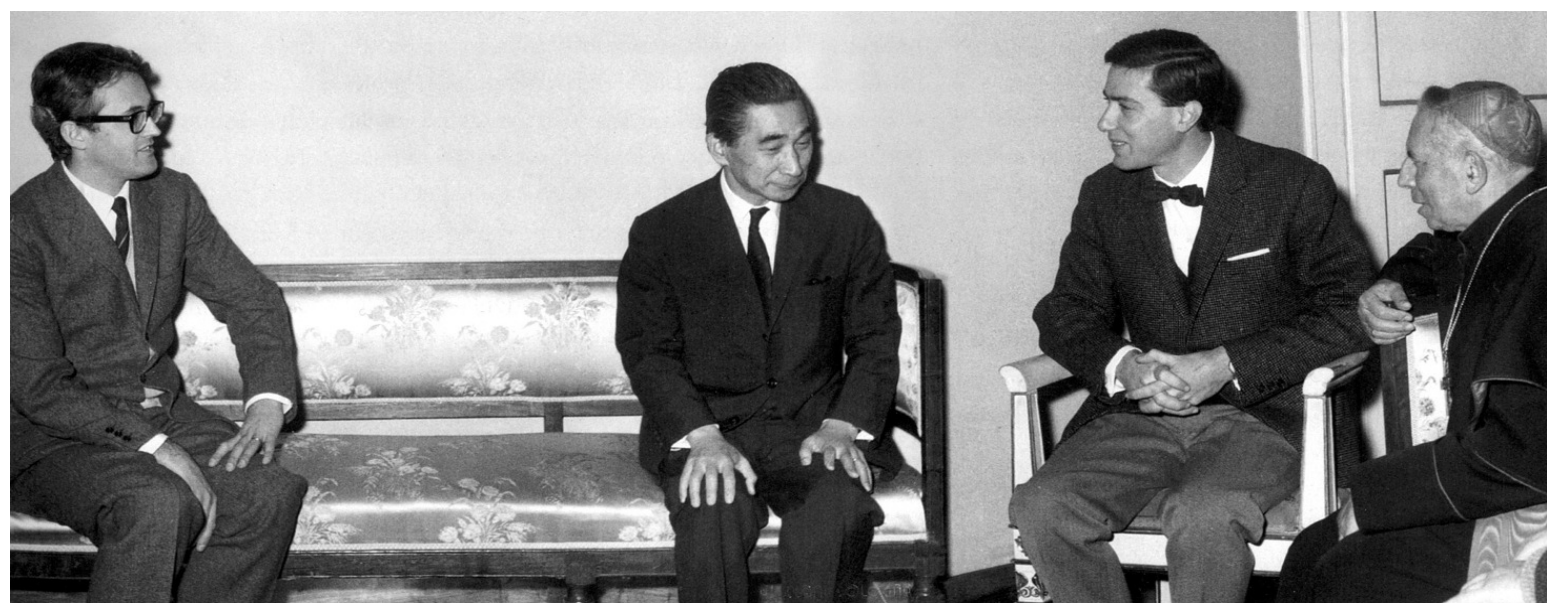

Fig. 14. Glauco Gresleri, Kenzo Tange, Francesco Scolozzi y el cardenal Lercaro. Bolonia, septiembre de 1966.

Los puntos clave de la arquitectura para la liturgia fueron el Calvario de piedra — sede de la custodia con sagrario- de Costantino Ruggeri (Fig. 17) y la colocación sobre él del conmovedor tríptico de estilo otoniano, en madera policromada; y finalmente, la disposición de la Pietà dei Lombardi —un grupo escultórico realizado en terracota - plenamente restaurada y colocada sobre un basamento en un área lateral, con una relación altimétrica adecuada para su lectura por parte de los fieles.

El ambiente del lugar era de una alta intensidad mística. El conjunto de la crucifixión, por su relación de proporcionalidad y proximidad con el espacio de la asamblea, resaltaba con excepcional evidencia, cumpliendo - con las figuras talladas en madera del mismo conjunto- el sentido de acogimiento de la cuncta familia Dei, perfecto para convertir en absolutamente real la participación activa.

El proyecto da la vuelta al mundo. Desde muchos países llegan a la revista y al centro felicitaciones, peticiones de imágenes y de noticias adicionales. La intervención se convierte en una referencia precisa para muchas obras de reestructuración litúrgica que varias diócesis acometieron en los años sucesivos para la adaptación de sus catedrales.

Cabe señalar que al ordenar la recuperación litúrgica de la cripta, Lercaro expresó su voluntad de que la misma cripta se convirtiese en el lugar de su sepultura, al unir - con la última ubicación de sus restos mortales - la larga obra de su vida a favor de la renovación litúrgica, con su pasión por la ciudad de Bolonia. Pero la última voluntad de Lercaro no fue respetada, y llegado el momento, se dispuso para sus restos mortales un nicho en un pilar lateral de la nave superior, mientras que en el sitio de la cripta elegido por el difunto arzobispo se colocó la nueva caldera para la calefacción. La historia es impredecible y, a veces, implacable.

Ciertamente la intervención no había sido bien vista por el cabildo de la catedral, tal vez porque la decisión de Lercaro se había realizado con autonomía personal, según era su costumbre respecto a las cosas en las que creía firmemente. Pero el movimiento de agitación por parte de las altas esferas de la jerarquía boloñesa iba en aumento, y por supuesto el episodio de la cripta se inscribía dentro de la diáspora general, al punto de que en solo dos años se llegaría a la ruptura definitiva. Y la reacción drástica, obtusa e infamante se concretó (¿por casualidad o premeditadamente?) exactamente a los dos años de la inauguración de la nueva solución litúrgica de la cripta de la catedral de Bolonia. Es el mismo 12 de febrero, esta vez de 1968, la fecha del retiro del arzobispo de Bolonia de su amada diócesis.

Sobre las motivaciones del retiro, las crónicas han mencionado todos los posibles causantes, pero nadie ha 

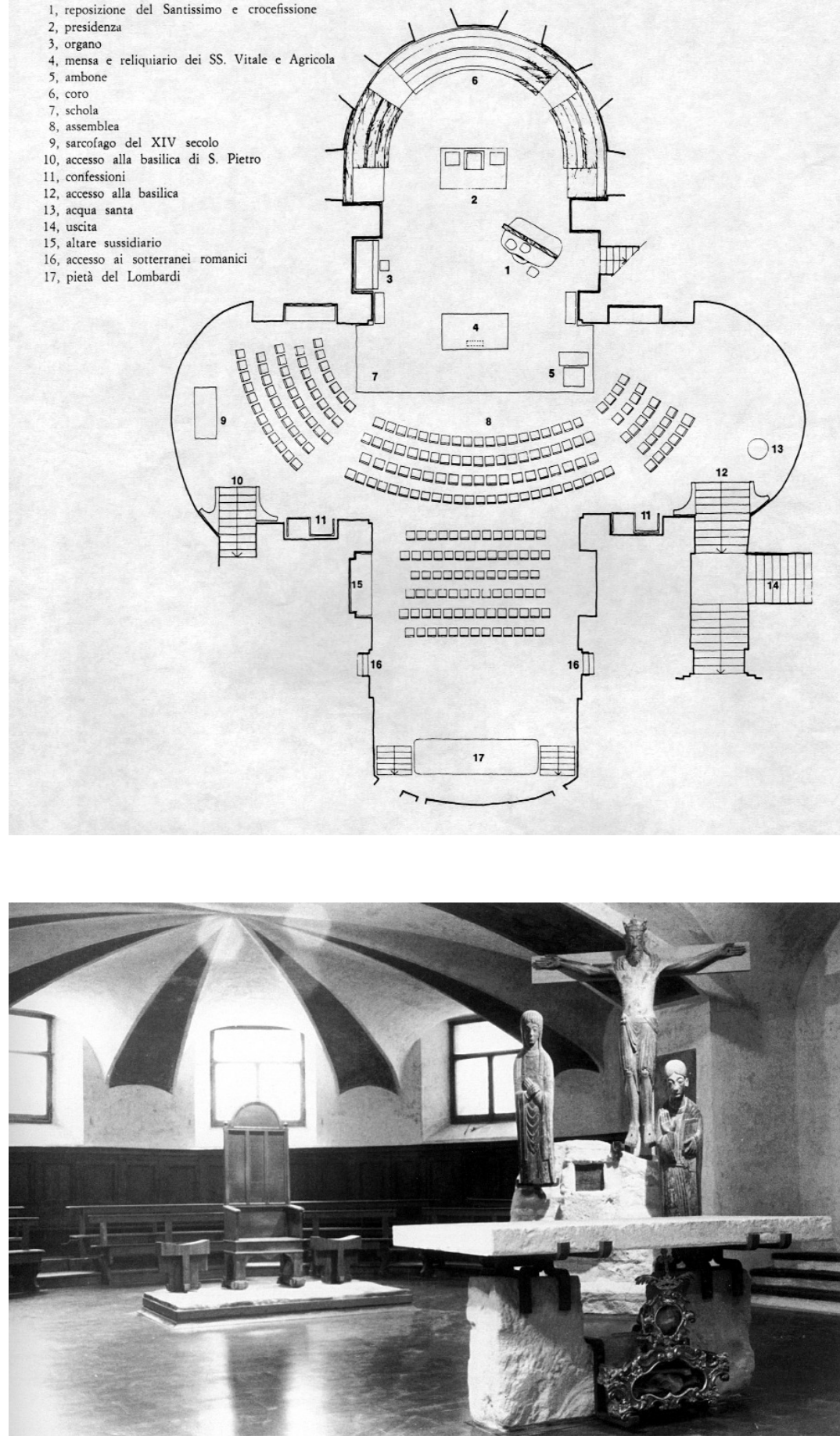

Fig. 15 y 16. Giorgio Trebbi, Glauco Gresleri, Giuliano Gresleri y Franco Scolozzi, reestructuración de la cripta de la catedral de San Pietro, Bolonia 1966, actualmente demolida. Planta e interior. 


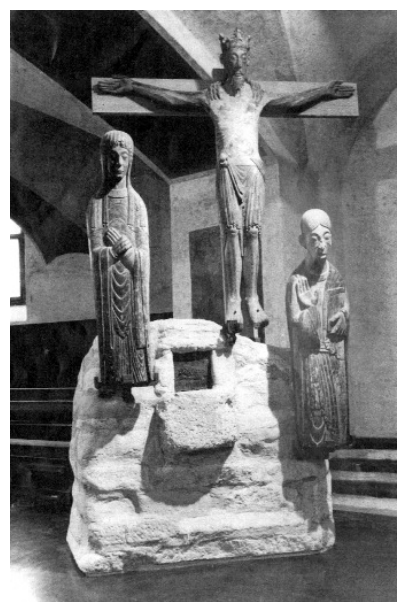

Fig. 17. Costantino Ruggeri OFM, Calvario de piedra con sagrario central para la cripta de la catedral de San Pietro, Bolonia 1966

tenido todavía el valor de desvelar la verdad de la maniobra oculta que partió de Bolonia y se concretó en la llegada del visitador apostólico Ernesto Civardi, que impone a Lercaro la renuncia a la cátedra boloñesa indicándola falsamente como voluntad del Santo Padre. Lercaro no se lo podía creer, y pide repetidamente a monseñor Civardi, por tres veces, confirmación de que dicha indicación venía personalmente del Pontífice. A la tercera falsa respuesta afirmativa del Visitador, Lercaro no pronuncia palabra y, quince días después redacta en unas pocas líneas su dimisión: «como me fue ordenado vine, como se me ordena me voy». El Mal, una vez más, había tomado la delantera, pues no estaba del todo dormido (Fig. 18).

La cripta fue cerrada durante años al público. Pero lo peor estaba por venir. Cuando el arzobispo Biffi decide ejecutar la reestructuración litúrgica de la nave superior, la cripta es considerada por los nuevos técnicos como una cantera de materiales. Con el desmontaje de las piezas constitutivas y la eliminación, tanto de la Crucifixión fijada sobre el Calvario como del Calvario mismo o el grupo de la Pietá, se ha llevado a cabo su destrucción completa.

La cripta de la catedral de San Pietro en Bolonia, símbolo de la contribución lercariana en el seno del Concilio Vaticano II, designada por Lercaro como su propio monumento sepulcral, demolida en sus elemen-

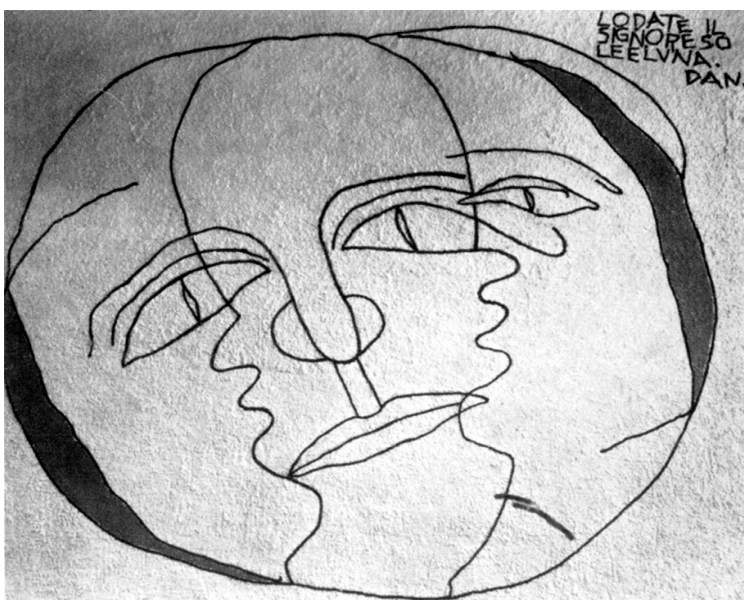

Fig. 18. Giuliano Gresleri, «Sole e luna», mural realizado en la iglesia parroquial de la Beata Vergine Immacolata (Glauco Gresleri, 1956/58).

tos fundamentales de validez litúrgica, ya no está entre las cosas que existen. Todavía no habían transcurrido los famosos cincuenta años y la Soprintendenza ha podido permanecer indiferente. La verdad es que a treinta y cinco años de su muerte, dentro del cúmulo de posiciones de disenso y de resistencia que parte de la alta jerarquía eclesiástica boloñesa puso claramente en acción contra la obra lercariana y su memoria, el expolio de la reorganización litúrgica de la cripta de la basílica metropolitana de Bolonia, por él querida como modelo, resulta de lo más llamativo. Su desaparición parece significar realmente el fin de aquella edad de oro para la Iglesia boloñesa, que había abierto los corazones y las mentes a los valores de la religiosidad de todos los ciudadanos, y que había dado un brillante ejemplo de la forma en que imaginaba el desarrollo de los principios litúrgicos que sólo la esencia científica de la arquitectura puede hacer explícitos y reconocibles.

\section{PROCEDENCIA DE LAS ILUSTRACIONES}

Fig. 1: Dmitri Kessel/Time \& Life Pictures/Getty Images, 1/1/54 (www.life.com/image/50393725, con acceso 7/10//11).

Fig. 2-6, 8-11, 14, 16 y 18: C+Q

Fig. 7: Archivo de la Fondazione Lercaro (Bolonia).

Fig. 12: Walter Breveglieri (www.flickr.com/photos/ilfattoquotidiano/sets/72157626798284305, con acceso el 29/9/11).

Fig. 15 y 17: Archivo Glauco Gresleri. 


\section{NOTAS}

(1) El Concilio Vaticano II (1962/65) se desarrolló en diversas sesiones. Al comienzo de la segunda sesión (septiembre de 1963) se nombraron cuatro moderadores: Krikor Bedros XV Agagianian, Patriarca de Cilicia de los Armenios, con sede en Beirut (Líbano); Leo Jozef Suenens, arzobispo de Malinas (Bélgica); Julius Döpfner, arzobispo de Munich y Freising (Alemania); y Giacomo Lercaro, arzobispo de Bolonia (Italia) (Nota del editor).

(2) Gresleri se refiere aquí a la iglesia parroquial de Sant'Eugenio papa, en via di Ravone 1 (Bolonia), asociada en su título a la antigua iglesia de Santa María Assunta di Casaglia. La constitución de esta nueva parroquia fue querida por el cardenal Giacomo Lercaro en 1961: primero se utilizó — provisionalmente - un garaje adaptado al uso litúrgico; luego, entre 1963 y 1973, se realizó la construcción definitiva bajo el proyecto de Luciano Lullini, La iglesia fue consagrada en 1974 por el cardenal Poma. Aunque terminada con muchas modificaciones con respecto al proyecto original, la iglesia se pone habitualmente como un ejemplo perfecto y armónico de integración con el espacio circundante (Nota del editor).

(3) En Italia, las Soprintendenze son órganos auxiliares del Ministerio de Cultura, que dependen de las Direcciones Regionales para los Bienes Culturales y del Paisaje (DRBCP), con competencias en cada ámbito territorial en materia de bienes culturales, paisajísticos, museísticos, archivísticos y afines (Nota del editor).

Fig. 19. (en la página siguiente) Glauco Gresleri conversa con algunos participantes, tras su intervención en el II Congreso Internacional de Arquitectura Religiosa Contemporánea (Ourense, 12 de noviembre de 2009 ). 
LERCARO Y EL PRINCIPIO DE LA ARQUITECTURA MODERNA AL SERVICIO DE LA LITURGIA

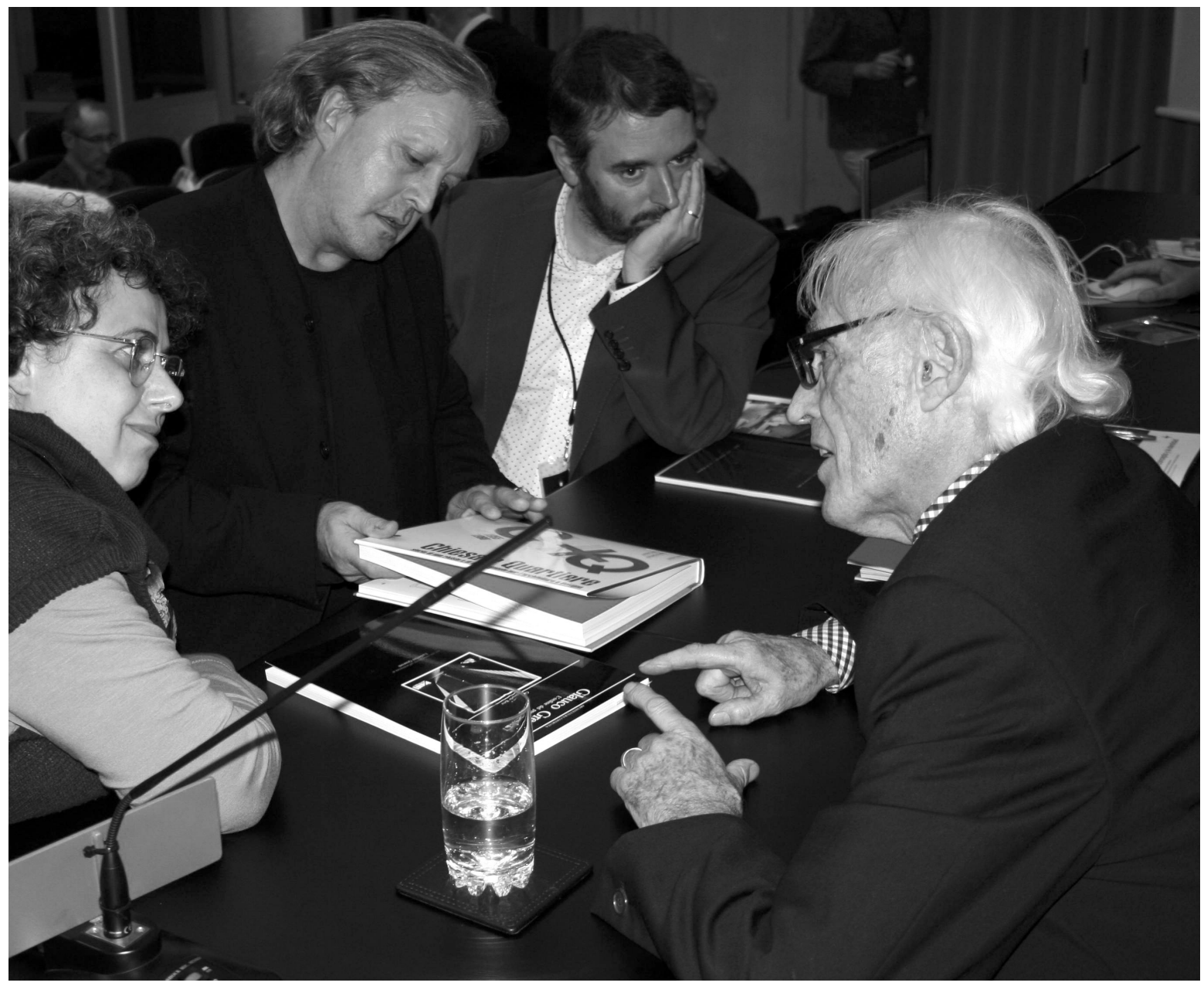

